\title{
STUDI KINETIKA EKSTRAK TUMBUHAN PATAH TULANG (EUPHORBIA TIRUCALLI) TERHADAP PENYEMBUHAN PADA KULIT
}

\author{
Mutiara Sukma*1 \\ ${ }^{1}$ Pendidikan Kimia,FMIPA, Universitas Negeri Padang, Indonesia \\ *Email : Mutiara337@gmail.com
}

\begin{abstract}
Abstrak. Studi ini bertujuan untuk membuat ekstrak dari tumbuhan patah tulang (Euphorbia tirucalli) terhadap penyembuhan pada kulit . Metode yang dilakukan adalah eksperimen dan uji aktivitas katalitik secara langsung. Tahapan pertama dilakukan dengan pembuatan ekstrak dari tumbuhan patah tulang (Euphorbia tirucalli) . Uji aktivitas langsung dilakukan dengan variasi berupa tetesan-tetesan selama 2-3 hari. Hasil eksperimen membuktikan bahwa ekstrak dari tumbuhan patah tulang (Euphorbia tirucalli) dapat menghilangkan tahi lalat yang membesar, menghilangkan kulit yang menebal atau kutil, mengeluarkan duri yang tertusuk pada kulit, serta meredakan patah tulang. Kondisi optimum ekstrak dari tumbuhan patah tulang tergantung kepada keluhan yang dialami. Penyembuhan ini diduga karena aktivitas katalitik ekstrak dari tumbuhan patah tulang (Euphorbia tirucalli) terhadap getah dan ranting atau dahannya.
\end{abstract}

Keywords : katalitik, ekstrak tumbuhan patah tulang (Euphorbia tirucalli), penyembuhan pada kulit .

\section{A. PENDAHULUAN}

Reaksi kimia [1] merupakan suatu perubahan yang menghasilkan senyawa baru. Dalam reaksi kimia yang terlibat didalam reaksi tersebut adalah reaktan. Perubahan yang terjadi dalam reaksi kimia yaitu perubahan secara kimiawi yang menghasilkan satu atau lebih senyawa baru yang biasa disebut sebagai produk. Perubahan-perubahan yang biasanya terjadi dalam reaksi kimia yaitu perubahan warna [2], timbulnya gas [3], adanya endapan [4], dan perubahan suhu [5]. Biasanya dalam reaksi kimia adanya suatu katalis, dimana katalis digunakan untuk mempercepat terjadinya suatu reaksi kimia. 
Katalis atau katalitik [6] merupakan zat yang dapat mempercepat terjadi nya suatu reaksi kimia yang berperan dalam suatu reaksi. Katalis dibedakan menjadi katalis heterogen [7] dan katalis homogen [8], katalis heterogen merupakan katalis yang memiliki fasa yang berbeda dengan pereaksinya dalam reaksi kimia [9] dan katalis homogen merupakan katalis yang memiliki fasa yang sama dengan pereaksinya dalam suatu reaksi kimia [10].

Tumbuhan patah tulang [11] memiliki nama latin Euphorbia tirucalli berasal dari Afrika tropis. Tumbuhan ini termasuk dalam genus Euphorbia, spesies E.tirucalli, dan famili Euphorbiaceae. Tumbuhan patah tulang (Euphorbia tirucalli) [12] di Sunda dikenal dengan susuran, [13] di Jawa dikenal dengan kayu arip, pacing tawa, tikel balung sedang [14] di Madura dikenal sebagai kayu langtolangan,kayu jaliso, kayu leso, kayu tabar [15].

Tumbuhan patah tulang (Euphorbia tirucalli) ini dapat ditemukan didataran rendah [16]. Tumbuhan patah tulang (Euphorbia tirucalli) memiliki pangkal yang berkayu dan cabang yang banyak dan juga memiliki getah seperti susu. [17] Tumbuhan ini memiliki ranting yang menyerupai pensil yang berwarna hijau. Daunnya terdapat pada ujung ranting [18] yang berukuran kecil [19]. Bunga pada tumbuhan patah tulang (Euphorbia tirucalli) ini biasanya tersusun dalam mangkuk dan akan keluar pada ujung rantingnya. [20] Tumbuhan patah tulang (Euphorbia tirucalli) tidak memiliki daun dan hanya tersusun atas batang yang menyerupai tulang belulang yang merupakan ciri khas pada tumbuhan ini [21]. [22] Dan getah yang terkandung pada tumbuhan ini secara empiris terbukti dapat mengobati luka [23].

Tumbuhan patah tulang (Euphorbia tirucalli) yang paling sering dimanfaatkan untuk obat [24] yaitu bagian kulit batang, ranting, maupun getahnya. [25] Dimana penggunaan tumbuhan ini dapat mencegah beberapa penyakit pada kulit diantaranya mencegah tahi lalat membesar, kapalan dan kutil, kulit tertusuk dari duri atau terkena pecahan kaca bahkan juga dapat menyembuhkan sakit gigi. Tumbuhan patah tulang (Euphorbia tirucalli) mengandung glikosid [26], sapogenin [27], terpenoid [28], alkaloid [29], tannin [30]. Pada getah tanaman patah tulang (Euphorbia tirucalli) ini mengandung senyawa euforbon [31], taraksasterol 
[32], $\alpha$ - Laktuserol [33], eufol [34] dan senyawa damar [35]. Tujuan dari penelitian ini yaitu untuk mengetahui apakah ekstrak dari tumbuhan patah tulang (Euphorbia tirucalli) mampu menyembuhkan luka atau kelainan pada kulit.

\section{B. METODE}

\section{Alat dan Bahan}

Peralatan yang digunakan untuk membuat ekstrak dari tumbuhan patah tulang ini sebagai berikut :
a. Wadah (Tuppeware)
b. Penyaring Plastik (Nagata)
c. Alat Untuk Merebus (Steele)
d. Blender (Philips)
e. Pisau (Joyko)
f. Cotton bods

Bahan yang digunakan untuk membuat ekstrak dari tumbuhan patah tulang ini sebagai berikut :
a. Dahan dari tumbuhan patah tulang.
b. Ranting dari tumbuhan patah tulang.
c. Getah yang didapat dari tumbuhan patah tulang.
d. Perasan dari air jeruk.
e. Air (Aqua).

1. Prosedur Kerja
a. Penyiapan Sampel 
Sampel yang digunakan diambil dari salah satu tanaman warga di Jalan Gajah IV No.12 Air Tawar Barat, Padang Utara. Sampel yang diambil sebanyak 1 kg. Sampel yang diambil terlebih dahulu dicuci.

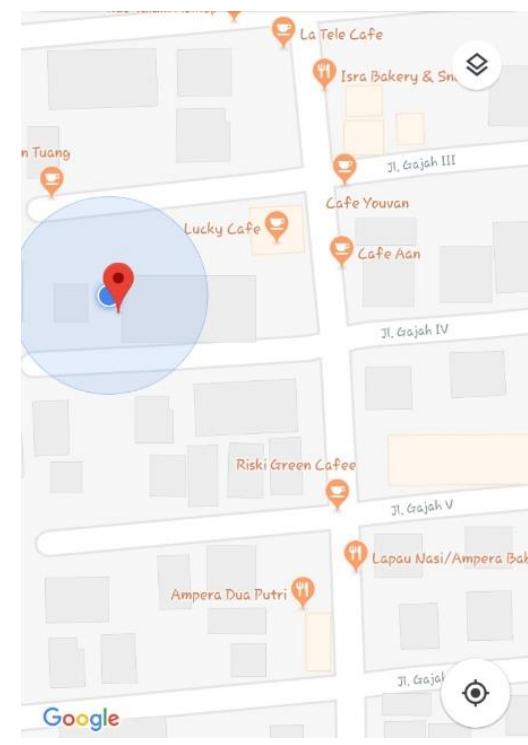

Gambar 1. Lokasi pengambilan sampel.

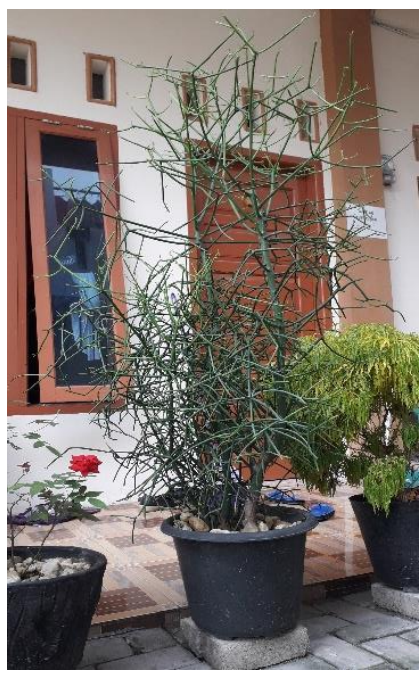

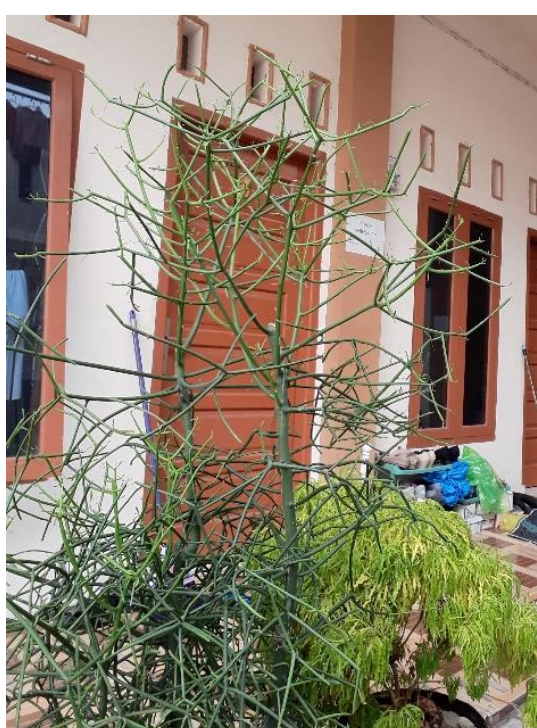

Gambar 2. Tumbuhan Patah Tulang (sukma, 2019)

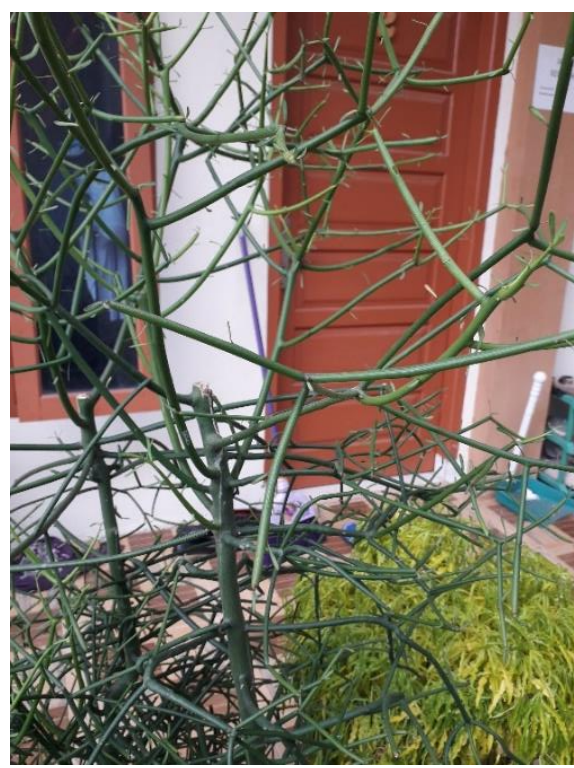

Gambar 3. Tumbuhan Patah Tulang (sukma, 2019) Gambar 4. Ranting dan Dahan sampel (sukma, 2019)

b. Pembuatan Sampel

Pada tumbuhan patah tulang (Euphorbia tirucalli) ini ekstrak yang dihasilkan berupa getah, dimana cara memperoleh ekstrak atau getah tersebut dengan memotong-motong dahan sehingga diperoleh tetesan-tetesan dari getah pada dahan 
tersebut. Tergantung kepada penanganan yang dilakukan, untuk meredakan sakit pada patah tulang, beberapa dahan dan ranting digiling halus.

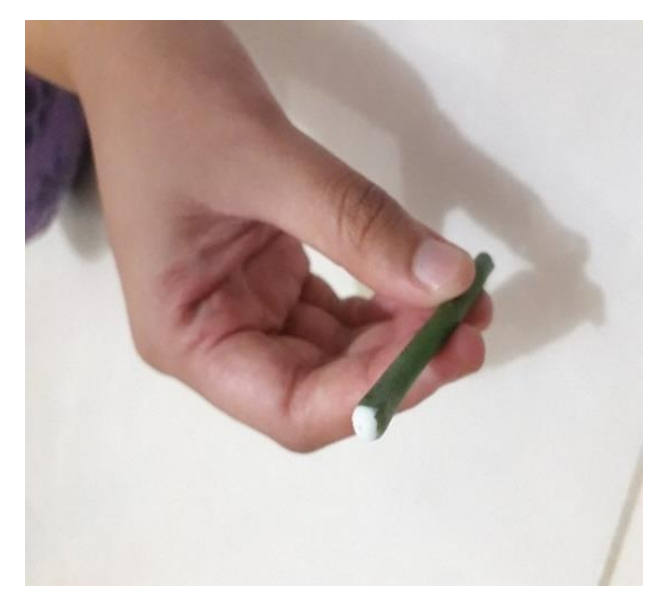

Gambar 5. Getah yang diperoleh (sukma, 2019)

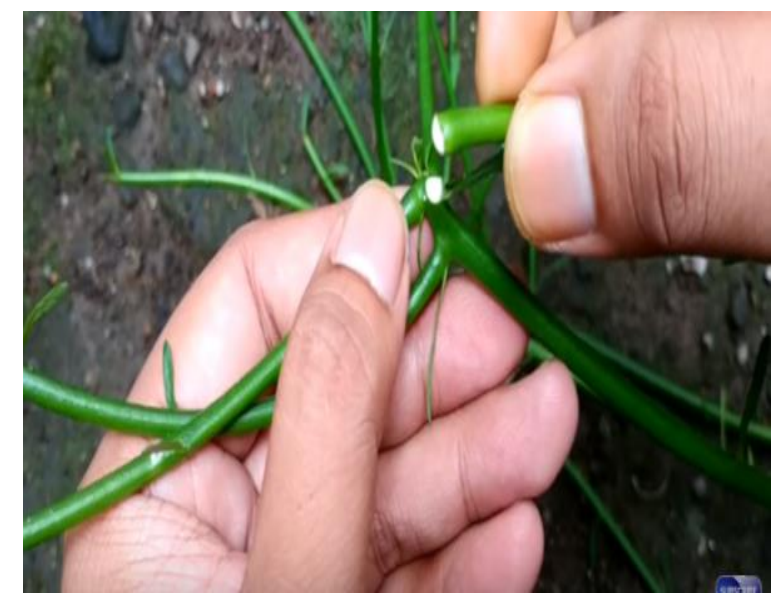

Gambar 6.

(https://www.youtube.com/watch?v=lyGoVTrtVIU)

c. Pengujian ekstrak

Ekstrak yang sudah ada dilakukan pengujian terhadap :

\begin{tabular}{|c|c|}
\hline Pengujian & Hasil dari pengujian \\
\hline $\begin{array}{l}\text { Untuk menghilangkan tahi lalat } \\
\text { yang membesar } \\
\text { Terlebih dahulu bersihkan tahi lalat } \\
\text { dengan air jeruk nipis } \\
\text { Olesi tahi lalat dengan } \\
\text { getah patah tulang } \\
\downarrow \\
\text { Lakukan beberapa }\end{array}$ & $\begin{array}{l}\text { Dari hasil pengujian didapatkan hasil } \\
\text { sebagaimana pemberian getah } \\
\text { dilakukan } 2 \text { hari dengan pemberian } \\
\text { dilakukan } 2 \text { kali sehari pagi dan sore. }\end{array}$ \\
\hline $\begin{array}{l}\text { 1. Untuk menghilangkan } \\
\text { kapalan dan kutil }\end{array}$ & $\begin{array}{l}\text { Dari hasil pengujian didapatkan hasil } \\
\text { yang dilakukan } 2 \text { hari dengan }\end{array}$ \\
\hline
\end{tabular}




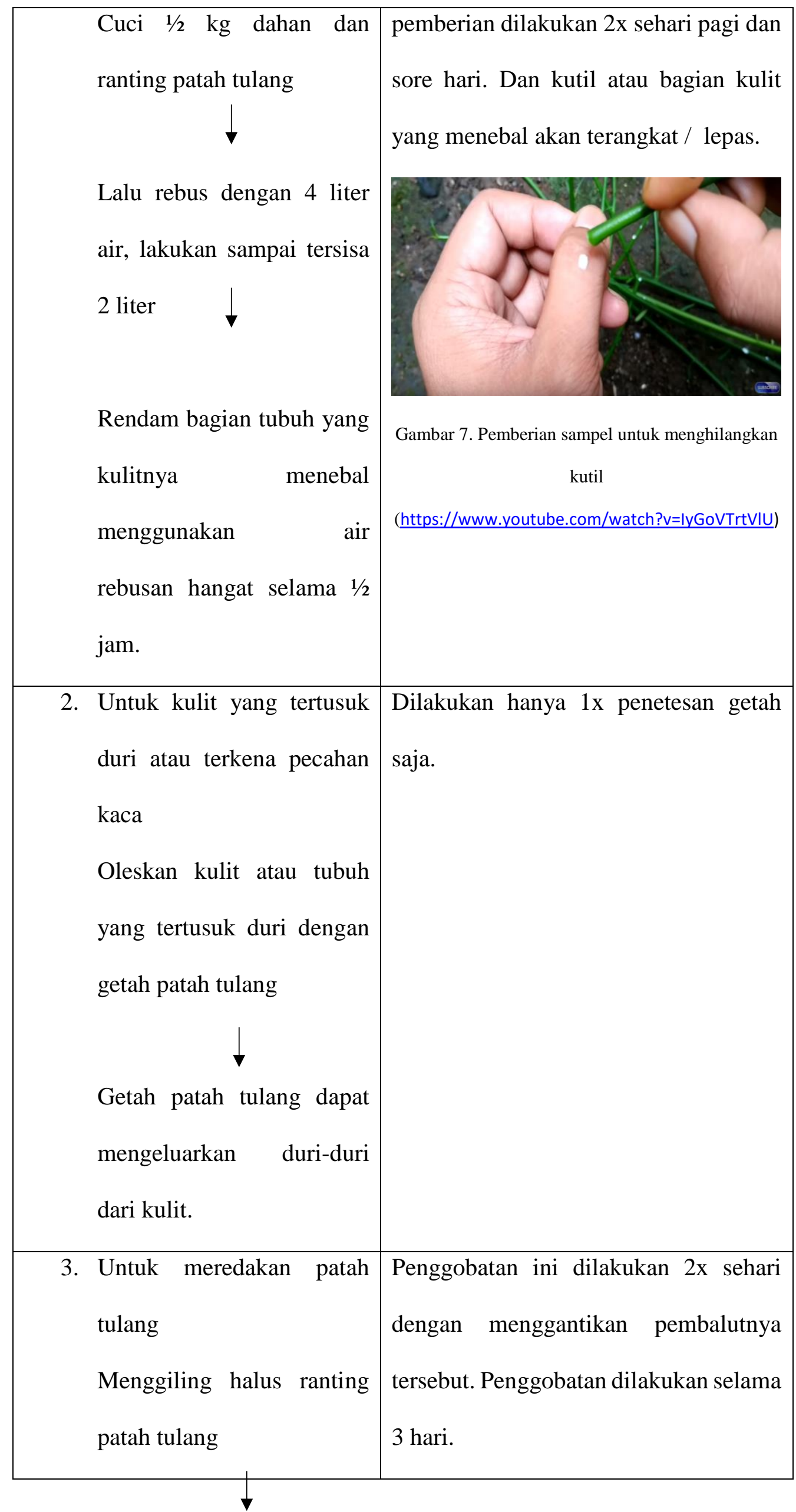


Menepelkan hasil gilingan

diatas tulang yang patah kemudian balut 


\section{HASIL}

\section{Hasil Pembuatan}

Hasil ekstrak atau getah yang diperoleh dari 1kilogram ranting atau dahan tumbuhan patah tulang sebanyak $5 \mathrm{ml}$. Hal ini dapat dilihat pada gambar berikut :
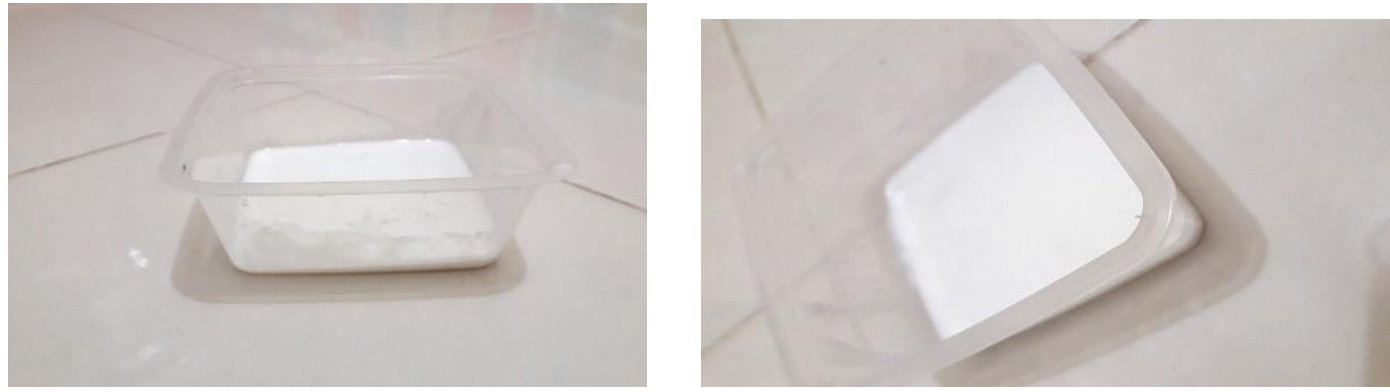

Gambar 8. Hasil ekstrak atau getah yang diperoleh (sukma, 2019)

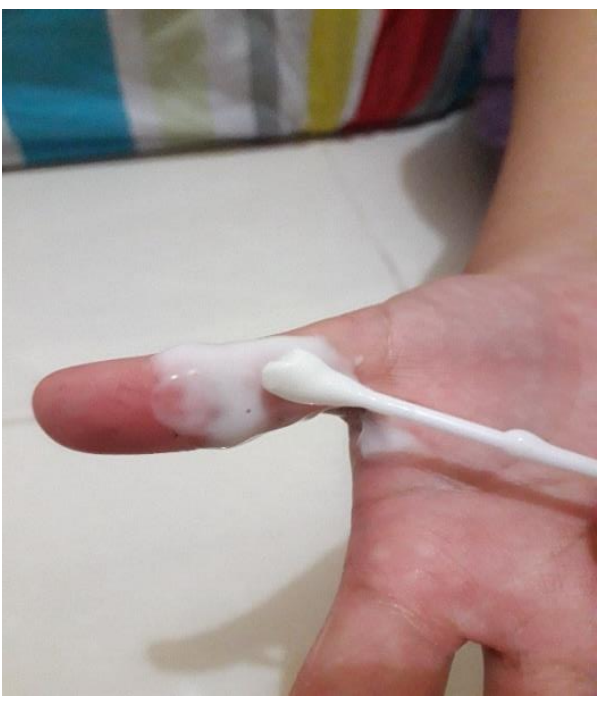

Gambar 9. Pengujian paa kutil (sukma, 2019)

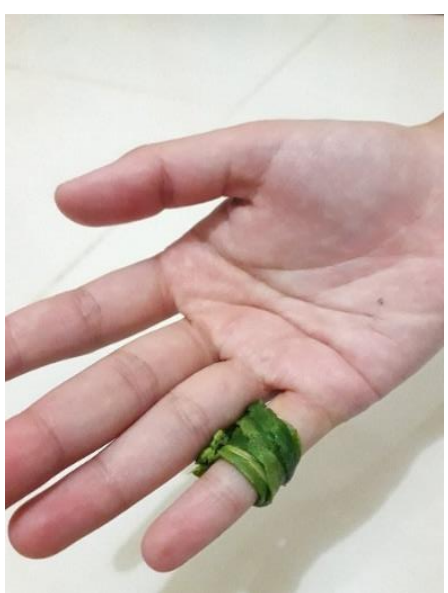

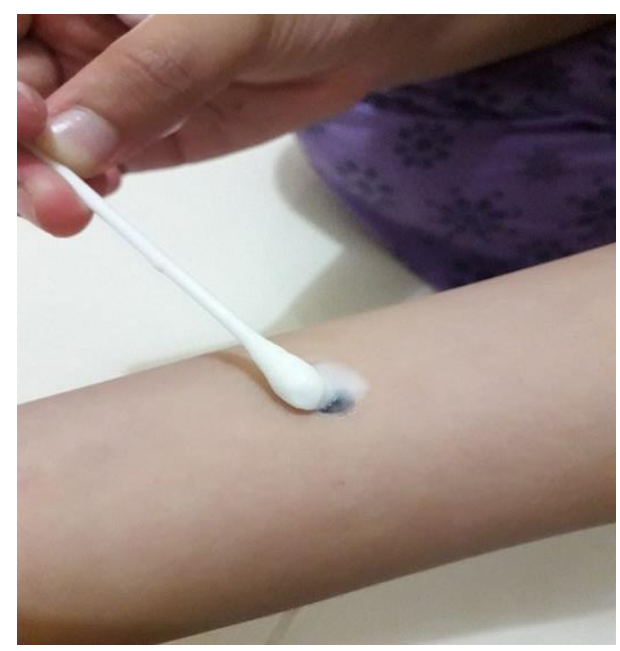

Gambar 10. Pengujian pada tahi lalat yang membesar (Sukma,2019)

Gambar 11. Pengujian pada tulang yang patah (sukma, 2019) 


\section{Hasil Uji Coba}

Tabel 1. Penyembuhan pada kulit dari hari ke-1 hingga hari ke-3

\begin{tabular}{|c|c|c|c|c|}
\hline No. & Pengujian & Hari ke- 1 & Hari ke -2 & Hari ke- 3 \\
\hline 1. & $\begin{array}{l}\text { Untuk menghilangkan } \\
\text { tahi lalat yang } \\
\text { membesar (A) }\end{array}$ & $\begin{array}{l}6 \text { tetesan } \\
(3 \mathrm{ml})\end{array}$ & $\begin{array}{l}4 \text { tetesan } \\
(2 \mathrm{ml})\end{array}$ & - \\
\hline 2. & $\begin{array}{l}\text { Untuk menghilangkan } \\
\text { kapalan dan kutil (B) }\end{array}$ & $\begin{array}{l}8 \text { tetesan } \\
(4 \mathrm{ml})\end{array}$ & $\begin{array}{l}6 \text { tetesan } \\
(3 \mathrm{ml})\end{array}$ & - \\
\hline 3. & $\begin{array}{l}\text { Untuk kulit yang } \\
\text { tertusuk duri atau } \\
\text { terkena pecahan kaca } \\
\text { (C) }\end{array}$ & 4 tetes $(2 \mathrm{ml})$ & - & - \\
\hline 4. & $\begin{array}{l}\text { Untuk meredakan patah } \\
\text { tulang (D) }\end{array}$ & $\begin{array}{l}\text { 500gr ranting } \\
\text { atau dahan } \\
\text { yang } \\
\text { dihaluskan. } \\
\text { Setara } \\
\text { dengan } 50 \mathrm{ml}\end{array}$ & $\begin{array}{l}\text { 250gr ranting } \\
\text { atau dahan } \\
\text { yang } \\
\text { dihaluskan. } \\
\text { Setara } \\
\text { dengan } 25 \mathrm{ml}\end{array}$ & $\begin{array}{l}\text { 200gr ranting } \\
\text { atau dahan } \\
\text { yang } \\
\text { dihaluskan. } \\
\text { Setara } \\
\text { dengan } 20 \mathrm{ml}\end{array}$ \\
\hline
\end{tabular}

\section{PEMBAHASAN}

Tanaman patah tulang (Euphorbia tirucalli) merupakan salah satu tanaman yang dapat menyembuhkan berbagai macam penyakit atau gangguan yang dialami pada kulit. Pengobatan dengan tumbuhan daun patah tulang ini sesuai dengan penyembuhan yang dilakukan dan tidak 
perlu mengeluarkan biaya. Untuk proses penyembuhan menghilangkan tahi lalat yang membesar, menghilangkan kutil, menghilangkan duri yang masuk cukup dengan meneteskan ekstrak atau getah yang ada pada tumbuhan patah tulang (Euphorbia tirucalli). Sedangkan penyembuhan patah tulang ranting atau dahan harus dihaluskan terlbeih dahulu.

Dalam proses penyembuhan sampel yang diperlukan sebanyak $1 \mathrm{~kg}$. Penyembuhan menghilangkan tahi lalat yang membesar untuk hari pertama diperlukan 8 tetes dimana 4 tetes dipakai pada pagi hari dan 4 tetes dipakai pada sore hari apabila dijadikan ke milliliter untuk hari pertama dibutuhkan $4 \mathrm{ml}$, untuk hari kedua sebanyak 6 tetes dimana 3 tetes pada pagi hari dan 3 tetes untuk sore hari, apabila dijadikan ke millimeter untuk hari kedua dibutuhkan $3 \mathrm{ml}$, untuk hari ketiga tahi lalat yang membesar sudah menyusut.

Penyembuhan menghilangkan kutil untuk hari pertama diperlukan 6 tetes dimana 3 tetes dipakai pada pagi hari dan 3 tetes dipakai pada sore hari apabila dijadikan ke milliliter untuk hari pertama dibutuhkan $3 \mathrm{ml}$, untuk hari kedua sebanyak 4 tetes dimana 2 tetes pada pagi hari dan 2 tetes untuk sore hari, apabila dijadikan ke millimeter untuk hari kedua dibutuhkan 2 ml, untuk hari ketiga kutil atau kulit yang menebal akan hilang.

Penyembuhan untuk kulit yang tertusuk duri dan pecahan kaca penyembuhannya satu kali saja, dimana saat pemberian 4 tetes getah atau setara dengan $2 \mathrm{ml}$.

Penyembuhan untuk meredakan tulang yang patah untuk hari pertama diperlukan sampel sebanyak 500 gr ranting atau dahan yang dihaluskan dipakai 2 kali sehari, 500 gr apabila dijadikan kedalam bentuk cairan / getah setara dengan $50 \mathrm{ml}$, untuk hari kedua diperlukan sampel sebanyak 250 gr ranting atau dahan yang dihaluskan dipakai 2 kali sehari, 250 gr apabila dijadikan kedalam bentuk cairan / getah setara dengan $25 \mathrm{ml}$, untuk hari ketiga diperlukan sampel sebanyak 200 gr ranting atau dahan yang dihaluskan dipakai 2 kali sehari, 200 gr apabila dijadikan kedalam bentuk cairan / getah setara dengan $20 \mathrm{ml}$ hingga bagian yang patah dapat 
diredakan dengan halusan dari ranting atau dahan dari tumbuhan patah tulang (Euphorbia tirucalli).

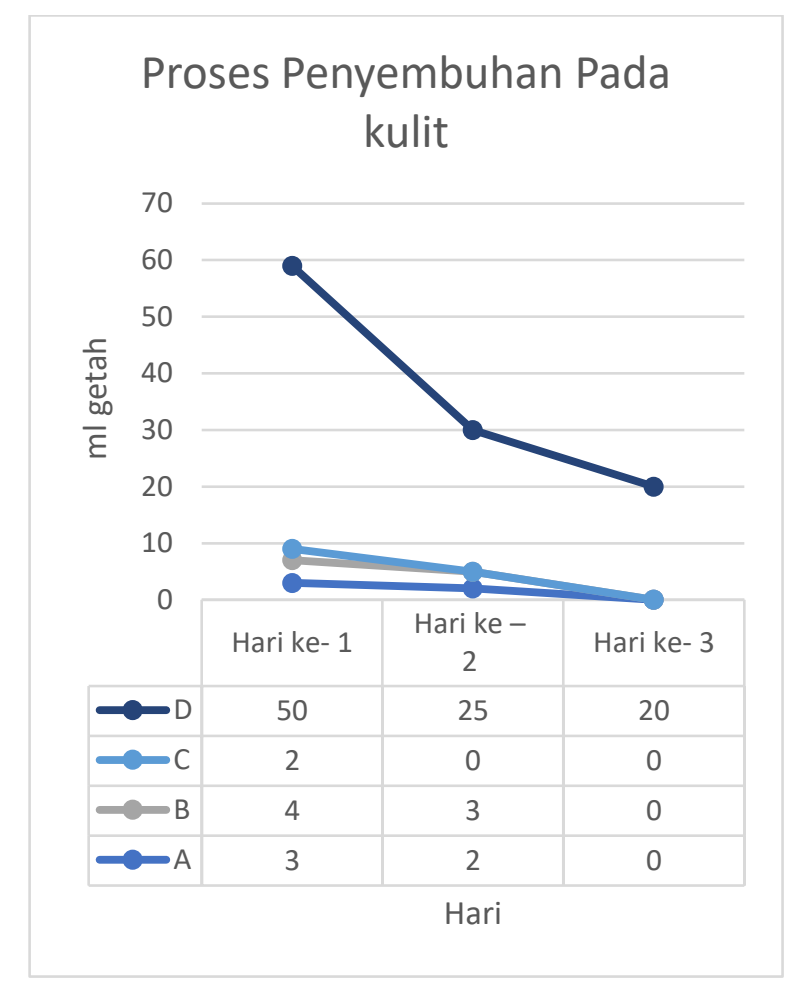

Pada kurva diatas terlihat bahwa dalam 2-3 hari penggunaan tumbuhan patah tulang (Euphorbia tirucalli) dapat menyembuhkan penyakit atau gangguan pada kulit.

Tanaman patah tulang (Euphorbia tirucalli) memang memiliki khasiat yang banyak dalam penyembukan pada kulit, menurut penelitian tanaman patah tulang (Euphorbia tirucalli) ini memiliki kandungan didalamnya berupa glikosida, sapogenin, terpenoid, alkaloid, tanin. Pada getah tanaman patah tulang (Euphorbia tirucalli) ini mengandung senyawa euforbon, taraksasterol, $\alpha$ - Laktuserol, eufol dan senyawa damar. Berikut adalah struktur kimia nya :

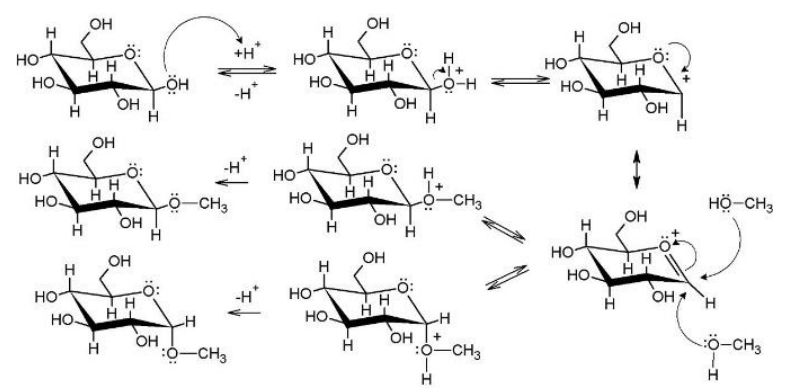

Gambar. Glikosida 


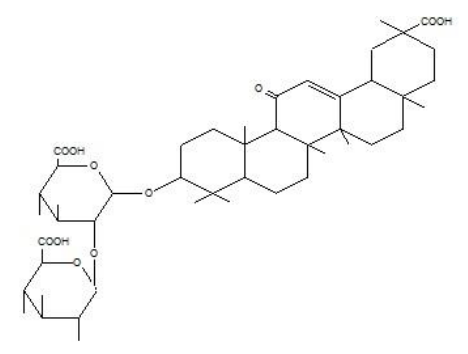

Gambar. Sapogenin<smiles>O=c1c(O)c(-c2ccc(O)c(O)c2)oc2cc(O)ccc12</smiles>

Gambar. Terpenoid<smiles>NC(Cc1ccc(O)c(O)c1)C(=O)O</smiles>

Gambar. Alkaloid

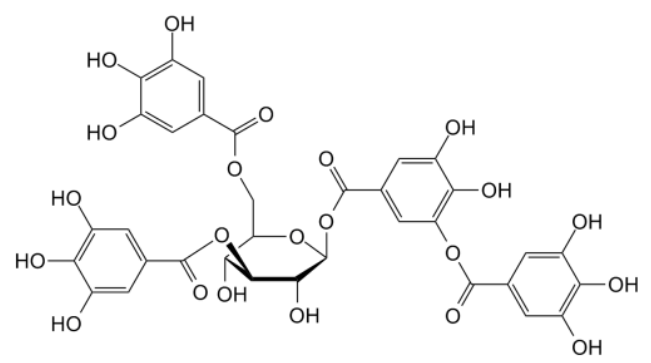

Gambar. Tanin 
Menurut penelitian, tanaman patah tulang (Euphorbia tirucalli) memiliki zat anti bakteri yang terkandung didalam nya adalah tannin. Dimana tannin merupakan zat yang pahit polyphenol yang cepat mengikat atau mengecilkan protein sehingga tannin dapat digunakan sebagai anti bakteri karena tannin mempunyai gugus fenol, sehingga mempunyai sifat-sifat seperti alcohol yang dapat digunakan sebagai antimikroba.

\section{E. KESIMPULAN}

1. Ekstrak dari tanaman patah tulang (Euphorbia tirucalli) diperoleh dari getah dan ranting yang dihaluskan.

2. Getah dari tanaman patah tulang (Euphorbia tirucalli) dapat menghilangkan tahi lalat, menghilangkan kutil atau daging yang membengkak dan mengeluarkan duri atau pecahan kaca yang mengenai kulit karena didalam nya mengandung glikosida, sapogenin, terpenoid, alkaloid, tanin.

3. Dengan adanya tannin yang memiliki sifat seperti alkohol yang bersifat sebagai antiseptik sehingga dapat digunakan sebagai antimikroba.

\section{REFERENSI}

[1]Altway, Ali, Winardi, Sugeng, Rachimoellah, M . (2012) “Aplikasi Packet Diffusion Model untuk Menganalisis Pengaruh Fenomena Micromixing terhadap Jalannya Reaksi Kimia Paralel di dalam Reaktor Tangki reraduk Kontinyu dengan Aliran Umpan Terpisah”, Majalah Forum Teknik UGM , 28 (2). (2004) .

[2] Ningsih SK. (2017) "SINTESIS DAN KARAKTERISASI NANOPARTIKEL ZnO DOPED $\mathrm{Cu}^{2+}$ MELALUI METODA SOL-GEL" , EKSAKTA : Berkala Ilmiah Bidang MIPA, 18(02) .doi :10.24036/eksakta/vol18-iss02/51.

[3] Huda N. (2017) "PENGARUH EKSTRAK SAMBILOTO (Andrographis paniculata Nees.) TERHADAP SIKLUS ESTRUS MENCIT (Mus musculus L. Swiss Webster) “, EKSAKTA : Berkala Ilmiah Bidang MIPA, 18(02) . doi : 10.24036/eksakta/vol18-iss02/55.

[4] Sari A. (2017) "POTENSI ANTIOKSIDAN ALAMI PADA EKSTRAK DAUN JAMBLANG (Syzigium cumini (L.) Skeels)", EKSAKTA : Berkala Ilmiah Bidang MIPA, 18 (02) . doi : 10.24036/eksakta/vol18-iss02/61. 
[5] Mulia M. (2017) "ISOLASI KUMARIN DARI KULIT BUAH LIMAU SUNDAI (Citrus nobilis Lour)", EKSAKTA : Berkala Ilmiah Bidang MIPA, 18 (02). doi : 10.24036/eksakta/vol18-iss02/70

[6] Retnowati, Diah Susetyo . (2011) "PEMUTIHAN ENCENG GONDOK MENGGUNAKAN $\mathrm{H}_{2} \mathrm{O}_{2}$ DENGAN KATALISATOR NATRIUM BIKARBONAT" , Dept. of Chemical Engineering, Diponegoro University, 12(1), Juni 2008.

[7] Tutuarima T. (2017) "SIFAT FISIK DAN KIMIA MARMALADE JERUK KALAMANSI (Citrus microcarpa) : KAJIAN KONSENTRASI PEKTIN DAN SUKROSA Physical and Chemical Properties of Marmalade Citrus of Calamondin (Citrus microcarpa) : Study of Pectin and Sucrose Concentrations", EKSAKTA : Berkala Ilmiah Bidang MIPA, 18(02). Doi : 10.24036/eksakta/vol18-iss02/73

[8] Zainul,R ., Alif, A., Aziz, H ., Arief, S ., Syukri \& Munaf, E . (2015) "Design of Photovoltaic Cell with Copper Oxide Electrode by using Indoor Lights", Research Journal of Pharmaceutical Biological and Chemical Science . Jilid 6, Terbitan 4, pp. 353-361.

[9] Zainul, R . (2016) "Design and Modification of Copper Oxide Electrodes for Improving Conversion Coefficient Indoors Lights (PV-Cell) Photocells . INA-Rxiv

[10] Zainul, R ., Alif, A ., Aziz, H ., Arief, S \& Darajat, S . (2015) "Modifikasi dan Karakteristik I-V Sel Fotovoltaik $\mathrm{Cu}_{2} \mathrm{O} / \mathrm{Cu}-\mathrm{Gel} \mathrm{Na} 2 \mathrm{SO} 4$ Melalui Illuminasi Lampu Neon", EKSAKTA : Berkala Ilmiah Bidang MIPA . Jilid 2, Terbitan 2, pp. 50.

[11] Agral, Omega, Fatimawali, Fatimawali, Yamlean, Paulina V.Y, Supriati, Hamidah Sri . (2013). "FORMULASI DAN UJI KELAYAKAN SEDIAAN KRIM ANTI INFLAMASI GETAH TANAMAN PATAH TULANG (Euphorbia tirucalli L)", PHARMACON , 2(3).

[12] Zainul, R ., Oktavia, B ., Dewata, I \& Efendi, J . (2018) "Thermal and Surface Evaluation on The Process of Forming a $\mathrm{Cu}_{2} \mathrm{O} / \mathrm{CuO}$ Semiconductor Photocatalyst on a Thin Copper Plate", IOP Conference Series: Materials Science and Engineering, Jilid 335, Terbitan 1 . pp. 012039.

[13] Zainul, R . (2016) "Determination of the half-life and the quantum yield of $\mathrm{ZnO}$ semiconductor photocatalyst in humic acid, INA-Rxiv.

[14] Zainul, R . (2016) "Effect of Temperature and Particle Motion against the ability of ZnO Semiconductor Photocatalyst in Humic Acid", INA-Rxiv.

[15] Sesilia I. Napa, Theo Da Cunha, Yohanes Buang . (2001) "Antibacterial Activities of Ranting Patah Tulang (Euphorbia tirucalli)", Extract: Short Communication . Journal of Applied Chemical Science, 2(1).

[16] Zainul, R ., Alif, A ., Aziz, H \& Arief, S . (2015) . "Disain Geometri Reaktor Fotosel Cahaya Ruang:", Jurnal Riset Kimia . Jilid 8, Terbitan 2.131.

[17] Toana, Moh. Hibban, Nasir, Burhanuddin . (2012) "STUDI BIOAKTIVITAS DAN ISOLASI SENYAWA BIOAKTIF TUMBUHAN Euphorbia tirucalli L. (EUPHORBIACEAE) SEBAGAI INSEKTISIDA BOTANI ALTERNATIF “, AGROLAND, 17(1).

[18] Setiorini, Melina Scandinovita, Soegihardjo, C.J., Atmodjo, Kianto . (2016) "POTENSI ANTIMIKROBIA KRIM EKSTRAK RANTING PATAH TULANG (Euphorbia tirucalli 
Linn.) TERHADAP Propionibacterium acnes ATCC 11827 DAN Candida albicans ATCC 24433”, Sanata Dharma University, 11(2).

[19] Anwar, M ., Munaf, E ., Kosela, S ., Wibowo, W \& Zainul, R . (2015) "Study of Pb(II) Biosorption from Aqueous Solution Using Immobilized Spirogyra Subsalsa Biomass", Journal of Chemical and Pharmaceutical Research, Jilid 7, Terbitan 11, pp. 715-722.

[20] Oratmangun, Sandriani A. (2014) "UJI TOKSISITAS EKSTRAK TANAMAN PATAH TULANG (Euphorbia tirucalli L.) TERHADAP Artemia salina DENGAN METODE BRINE SHRIMP LETHALITY TEST (BSLT) SEBAGAI STUDI PENDAHULUAN POTENSI ANTI KANKER", PHARMACON, 3(3).

[21] Yasthopi, A ., Zainul, R ., Alif, A ., Aziz, H ., Arief, S \& Syukri . (2015) "Photoelectrosplitting Water for Hydrogen Production Using Illumination with Indoor Lights", Journal of Chemical and Pharmaceutical Research. Jilid 7, Terbitan 9, pp. 57-67.

[22] Baud, Grace S., Sangi, Meiske S., Koleangan, Harry S.J. (2014) "ANALISIS SENYAWA METABOLIT SEKUNDER DAN UJI TOKSISITAS EKSTRAK ETANOL BATANG TANAMAN PATAH TULANG (Euphorbia tirucalli L.) DENGAN METODE Brine Shrimp Lethality Test (BSLT)", Sam Ratulangi University , 14(2).

[23] Kalangi, Sonny J R . (2013) "KHASIAT MADU PADA PENYEMBUHAN LUKA KULIT", JURNAL , 4(3).

[24] Alkalili, Dina . (2018) “:EFEKTIVITAS DAN KECEPATAN REAKSI EKSTRAK TUMBUHAN PATAH TULANG (Euphorbia tirucalli) TERHADAP KEMATIAN LARVA NYAMUK Aedes aegypti SEBAGAI PENGEMBANGAN EKOTOKSIKOLOGI", JURNAL PENELITIAN DAN KAJIAN ILMIAH KESEHATAN POLITEKNIK MEDICA FARMA HUSADA MATARAM, 4(2).

[25] Anhar, A ., Sumarmin, R \& Zainul, R . "2016) "Measurement of Glycemic Index of West Sumatera Local Rice Genotypes for Healthy Food Selection", Journal of Chemical and Pharmaceutical Research, Jilid 8, Terbitan 8, pp. 1035-1040.

[26] Sanjaya H. (2017) "DEGRADASI METHYLENE BLUE MENGGUNAKAN KATALIS ZnO-PEG DENGAN METODE FOTOSONOLISIS, EKSAKTA : Berkala Ilmiah Bidang MIPA, 18 (02) (2017) . doi. 10.24036/eksakta/vol18-iss02/45.

[27] Setianto S. (2017) “ANALISA KUANTITATIF CAMPURAN SENYAWA OKSIDA SEBAGAI DASAR IDENTIFIKASI KANDUNGAN BAHAN SUMBER DAYA ALAM Studi Kasus : Kandungan Mineral pada Pasir Besi di Pesisir Pantai Selatan, Jawa Barat" , EKSAKTA : Berkala Ilmiah Bidang MIPA. Doi : 10.24036/eksakta/vol18-iss02/74.

[28] Horiza H, Azhar M, Efendi J. (2017) "EKSTRAKSI DAN KARAKTERISASI INULIN DARI UMBI DAHLIA (Dahlia sp.L) SEGAR DAN DISIMPAN, EKSAKTA : Berkala Ilmiah Bidang MIPA, 18(01) . doi :10.24036/eksakta/vol18-iss01/14.

[29] Hary Sanjaya, Hardeli, Riri Syafitri . (2018) "DEGRADASI METIL VIOLET MENGGUNAKAN KATALIS ZnO-TiO2 SECARA FOTOSONOLISIS”, EKSAKTA, 19(1). doi : 10.24036/eksakta/vol19-iss01/131. 
[30] Khairani, Elsa Yuniarti, Ramadhan Sumarmin . (2018) "PENGARUH EKSTRAK KULIT BUAH MANGGIS (GARCINIA MANGOSTANA L.) TERHADAP HISTOLOGIS PANKREAS MENCIT (MUS MUSCULUS L. SWISS WEBSTER) YANG DIINDUKSI SUKROSA", EKSAKTA, 19 (1) . doi : 10.24036/eksakta/vol19-iss01/123.

[31] Syafei N. (2018) "Riset Material ANALISA FENOMENA KOROSI PELAT PIPA BAJA KARBON API 5L-X65 DALAM LARUTAN 7900 ML AIR LAUT DAN 100 ML AMONIAK PADA KONDISI GAS CO2 DAN H2S JENUH PADA SUHU RUANG”, EKSAKTA : Berkala Ilmiah Bidang MIPA, 19 (1) . doi : 10.24036/eksakta/vol19-iss1/83.

[32] Ruswandi R. (2018) "Determination of Fructose Content resulted by Inulin Hydrolysis with DNS as Oxidizer", EKSAKTA : Berkala Ilmiah Bidang MIPA, 19(1). doi : 10.24036/eksakta/vol19-iss1/102.

[33] Rizki Saputra M, Sumarmin R. (2018) "PENGARUH EKSTRAK DAUN SIRIH MERAH (Piper crocatum Ruiz \& Pav.) TERHADAP GLUKOSA DARAH MENCIT (Mus musculus L.) JANTAN YANG DIINDUKSI SUKROSA”, EKSAKTA : Berkala Ilmiah Bidang MIPA, 19(1) . doi : 10.24036/eksakta/vol19-iss 1/124.

[34] Advinda L. (2018) "PERTUMBUHAN STEK HORIZONTAL BATANG JARAK PAGAR (Jatropha curcas L.) YANG DIINTRODUKSI DENGAN PSEUDOMONAD FLUORESEN", EKSAKTA : Berkala Ilmiah Bidang MIPA , 19(1). doi : 10.24036/eksakta/vol19-iss1/129.

[35] Putri D, Fifendy M, putri M. (2018) "DIVERSITAS BAKTERI ENDOFIT PADA DAUN MUDA DAN TUA TUMBUHAN ANDALEH (Morus macroura miq.)”, EKSAKTA : Berkala Ilmiah Bidang MIPA, 19(1) . doi :10.24036/eksakta/vol19-iss1/122. 
